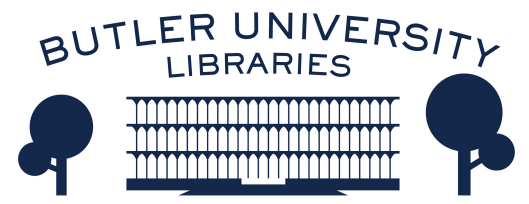

Journal of Hindu-Christian Studies

Volume 24

Article 15

November 2011

\title{
Book Review: "McDonaldisation, Masala McGospel and Om Economics: Televangelism in Contemporary India"
}

Chad M. Bauman

Follow this and additional works at: https://digitalcommons.butler.edu/jhcs

Part of the Religion Commons

\section{Recommended Citation}

Bauman, Chad M. (2011) "Book Review: "McDonaldisation, Masala McGospel and Om Economics: Televangelism in Contemporary India"," Journal of Hindu-Christian Studies: Vol. 24, Article 15.

Available at: https://doi.org/10.7825/2164-6279.1492

The Journal of Hindu-Christian Studies is a publication of the Society for Hindu-Christian Studies. The digital version is made available by Digital Commons @ Butler University. For questions about the Journal or the Society, please contact cbauman@butler.edu. For more information about Digital Commons @ Butler University, please contact digitalscholarship@butler.edu. 


\section{McDonaldisation, Masala McGospel and Om Economics: Televangelism in Contemporary India. By Jonathan D. James. Los Angeles: Sage, 2010, xxvii + 232.}

THE focus of this volume, based on fieldwork, interviews, surveys, and televangelism content analyses, is spelled out, though somewhat enigmatically, in its title. "McDonaldisation" and "Masala McGospel" refer, respectively, to the global and "glocal" variants of Charismatic televangelism available in India, while "Om Economics" refers to Hindu religious programming, which the author portrays primarily as a response to that produced by Christians.

Charismatic televangelism, James argues, represents a new phase in the evangelization of India, one which is having a profound impact across the spectrum of Indian Christianity. Among other effects, the four 24-hour Christian televangelism networks available in India are contributing to the charismaticization of Indian Christian theology, worship, hermeneutics, and organizational style. They also contribute to the propagation of what James considers the "materialistic and consumerist value system" of the United States. Televangelism, James asserts, both draws upon the long tradition of American revivalism that goes back to Charles Finney, Dwight Moody, and Billy Holiday, and also reflects the American gospel of health and wealth. "In other words," he writes, "the medium is a product of the American value system" (2).

The rise of Charismatic televangelism represents another shift as well. Given the fact that it is beamed into India largely without alteration, primarily from the United States, the United Kingdom, and Australia, Charismatic televangelism implicitly suggests that the Christian gospel requires no contextualization at all, that is, that Euro-American Christianity is the one and only authentic form of the faith, a fully (self-)sufficient, cultureless Christianity. In this, then, the phenomenon of global Christian televangelism bucks the trend of much contemporary Indian Christianity toward greater and greater "indigenization." (It should be noted, of course, that how much and to which
Indian culture Christianity should be "indigenized" remains a matter of great debate among contemporary Christians.) And this predominance of western forms of Christianity is perceptible even in "glocal" varieties of televangelism, which remain in the view of many Indian Christians and Hindus "two parts Indian and three parts American" (3).

James is at his best when he is comparing. For example, he notes that the appeals for support that are in global televangelism direct and omnipresent appear far less regularly, and in a more subdued fashion, in televangelism produced by Indian Christians. And whereas global televangelists speak frequently about politics (e.g., support for Israel, U.S. foreign policy), Indian Christian televangelists steer clear of political issues. Similarly, the madly roving preachers of global Christian televangelism are rarely to be found in Hindu religious programming, where the stationary, seated, and saffron-clad guru is the norm. In addition, while products are sold during Hindu religious programming, explicit appeals for direct financial support are almost never made.

James also includes some interesting material on the perceived cultural appropriateness of various forms of Christian televangelism. For example, some of James's informants, both Christian and Hindu, objected to the strongly anti-Muslim and anti-Hindu messages of televangelists like Pat Robertson. In fact, Robertson's anti-Hindu polemics have received so much negative attention that the Indian affiliate of CBN has had to distance itself from its parent company (113). James rightly situates this controversy in the context of broader Hindu concerns about Christianity, its association with and putative promotion of "western" culture and "western" foreign policy, its evangelical tendencies, its occasional demonization of Hinduism, and its foreign financial support (the Christian satellite stations in India are fully funded from abroad). Charismatic televangelism typifies all of these 
negative stereotypes of Christianity. "Therefore," James writes, "the perception is that televangelism is, at best, another carrier of Western, secular modernity, and at worst, part of an international conspiracy to divide India" (208).

The book is, unfortunately, beset by numerous and significant problems. It ranges broadly, so much so that the focus on Indian televangelism is for long stretches nearly completely lost. Moreover, the book frequently wanders in a desultory fashion into peripheral and sometimes completely irrelevant material (e.g., India's seven main "physical types," pg. 81) that not only distracts from the primary theme of the book, but also compels the author to deal with topics beyond his area of expertise (and to do so, because of space constraints, only cursorily). He argues, for example, that Hinduism influenced the development of Charismatic Christianity in the West. The argument is plausible, perhaps, but would require the marshaling of a great deal more evidence than he supplies. He also stumbles somewhat clumsily into debates about Indian Christian history, contending with some confidence that St. Thomas did indeed establish the Indian Christian community, and arguing again without the proper marshaling of evidence that early Indian Christian writing influenced the development of Tamil literature from the first century onwards (61). And his sources on Hinduism (e.g., H. P. Griswold, from 1912; L. S. S. O'Malley, from 1935) are often outdated and somewhat prone to essentialization.

There are, in addition, a number of methodological issues. For examples, James frequently includes suggestive lists where fuller explanations or arguments are necessary, and a number of his tables are organized confusingly. At times, he also reads a bit too much into his own survey data, and there is at least one blatant statistical error (on pg. 140, when a survey response given by 53 percent of 30 Charismatic pastors and 46 percent of 30 non-Charismatic pastors is said to have been given by a "combined 99 percent"). His content analysis involves the relatively superficial counting of particular words and phrases (e.g., "anointing in the spirit") without reference, as is the current trend today, to the context of those words, and their relationship to other words and phrases in the programming analyzed. $\mathrm{He}$ also leaves completely unexplored the audience's reception and understanding of these particular words and phrases, which, given the cross-cultural and multilingual elements involved in the Indian consumption of global televangelism, would have been an intriguing topic indeed.

Finally, the book also betrays a bias, subtle at first but more explicit towards the end, in favor of "pre-colonial" (particularly Syrian) forms of Christianity, which "maintained the fabric of Hindu culture while being Christian in faith and Syrian in liturgy" (209) and against Charismatic televangelism, which is "grounded in feelings and signs rather than theological objectivity" (xxii), rejects what are implied to be the true Christian understandings of "Christian discipleship and maturity" (5), reduces the "sacred act of worship...to a series of choices in the supermarket of Christianity" (199), and unlike "liturgy in Church" which "celebrates the sacrificial life of Christ...celebrates [instead] the life of the individual and objectifies the body..." (197).

McDonaldisation, Masala McGospel and $\mathrm{Om}$ Economics is therefore an eminently mixed bag, with some value and full of potential, much of it, unfortunately, unrealized.

Chad M. Bauman Butler University

\section{The South Indian Pentecostal Movement in the Twentieth Century. Michael Bergunder. Grand Rapids, Mich.: Wm. B. Eerdmans Publishing Company, 2008. xii+380 pp.}

